\title{
Size of Containers in the Production of Flamboyant Seedlings
}

\author{
Alan Mario Zuffo ${ }^{1}$, Fábio Steiner ${ }^{1}$, Aécio Busch ${ }^{1}$, Joacir Mario Zuffo Júnior ${ }^{2}$, Wéverson Lima Fonseca ${ }^{3}$, \\ Everton Vinicius Zambiazzi ${ }^{4}$, Alan Eduardo Seglin Mendes ${ }^{4}$, Isabella Maria Monteiro Borges ${ }^{4}$, \\ Sérgio Hebron Maia Godinho ${ }^{4} \&$ André Rodrigues Salomão Pinto ${ }^{4}$ \\ ${ }^{1}$ Department of Crop Production, State University of Mato Grosso do Sul, Cassilândia, Mato Grosso do Sul, \\ Brazil \\ ${ }^{2}$ Department of Agronomy, State University of Mato Grosso, Nova Xavantina, Mato Grosso, Brazil \\ ${ }^{3}$ Department of Crop Production, Federal University of Ceará, Fortaleza, Ceará, Brazil \\ ${ }^{4}$ Department of Agriculture, Federal University of Lavras, University Campus, Lavras, Minas Gerais, Brazil \\ Correspondence: Alan Mario Zuffo, Department of Crop Production, State University of Mato Grosso do Sul, \\ CEP: 79540-000, Cassilândia, Mato Grosso do Sul, Brazil. E-mail: alan_zuffo@hotmail.com
}

Received: September 24, 2017

Accepted: October 23, 2017 Online Published: November 15, 2017

doi:10.5539/jas.v9n12p99

URL: https://doi.org/10.5539/jas.v9n12p99

\begin{abstract}
The size of the container can affect the quality of the seedlings and, there is no recommendation of containers for the formation of flamboyant seedlings [Delonix regia (Bojerex Hook.) Raf]. Thus, the objective of this study was to evaluate the production of flamboyant seedlings in different container sizes, besides performing trail analysis to identify the growth variables that characterize the quality of these seedlings. The experimental design was a randomized block design with seven container sizes $(13 \times 13 \mathrm{~cm}, 15 \times 15 \mathrm{~cm}, 13 \times 20 \mathrm{~cm}, 15 \times 25 \mathrm{~cm}, 17 \times 22$ $\mathrm{cm}, 17 \times 30 \mathrm{~cm}$ or $30 \times 40 \mathrm{~cm}$ ), with four replicates. Each experimental unit was composed of five containers, totaling 20 containers per treatment. The plant height, stem base diameter, number of leaves and the sturdiness quotient were measured at 20,40,60,80 and 100 days after emergence (DAE), and at $100 \mathrm{DAE}$ were also measured the root volume, root dry matter, shoot dry matter, total dry matter, shoot/root dry matter ratio and Dickson quality index (DQI). The flamboyant seedlings have better grow when cultivated in polyethylene bags with size of $30 \times 40 \mathrm{~cm}$. The collar diameter, root volume, root dry matter, shoot dry matter and total dry matter are the most adequate variables to indicate the quality of flamboyant seedlings. However, because it is a rapid, simple and non-destructive measurement variable, the root collar diameter is more adequate to identify high-quality flamboyant seedlings.
\end{abstract}

Keywords: trail analysis, Delonix regia (Bojerex Hook.) Raf, Dickson quality index, seedling production

\section{Introduction}

The flamboyant [Delonix regia (Bojerex Hook.) Raf] belongs to the Fabaceae - Caesalpinioideae family and is native from Madagascar; the plant is used in reforestation and afforestation programs (Lorenzi et al., 2003). Due to its exotic nature and high adaptation ability to the tropical climate's environmental conditions, it has been used in the afforestation of squares and streets in every Brazilian region (Lucena et al., 2006; Ataíde et al., 2013).

Considering the flamboyant's ornamental potential, it is necessary to perform basic studies on the production of seedlings in different-sized containers, especially due to the lack of technical recommendations for this species. According to Oliveira et al. (2011), the production of arboreal species seedlings can be performed using containers of several types and sizes, from which the most used ones are polyethylene bags, due to their greater availability and smaller price.

The choice of the container's size is very important in seedling production because containers that have a volume that is superior to the recommended one result in unnecessary expenditures with substrates, use more nursery area, and increase the costs with transportation, maintenance, and distribution of the seedlings on the field, which directly affect the seedlings' final quality and cost (Oliveira et al., 2011; Cruz et al., 2016). The use of improper containers may result in the malformation of the seedlings' root system in the nursery, promoting an abnormal distribution of the side and top roots, which may result in a smaller level of survival of the seedlings in the field (Mafia et al., 2005; Lima et al., 2006). 
Regarding the production of forest seedlings, each species is influenced by the container's size. For example, for the Pacara earpod tree [Enterolobium contortisiliquum (Vell.) Morong], plastic bags with dimensions of $14 \times 20$ $\mathrm{cm}$ and capacity of $1,248 \mathrm{~cm}^{3}$ of substrate are recommended (Abreu et al., 2015). On the other hand, for the umbu tree [Spondias tuberosa Arruda Câmara], plastic bags of $15 \times 27 \mathrm{~cm}\left(1,900 \mathrm{~cm}^{3}\right)$ are recommended (Cruz et al., 2016).

The size of the proper container to produce seedlings will depend on the plant's growing rate, which may vary according to the species, climate conditions, and the type of substrate that is being used (Viana et al., 2008). For David et al. (2008), we need to identify the ideal container size for each species, considering that larger containers require a greater quantity of substrate, fertilizers, and nursery room.

In commercial nurseries, the standardization of the seedlings has been based especially on the different classes of height, favoring the technical fertilization and irrigation handling, specifically performed to improve the smaller seedlings' growth (Wendling et al., 2005). However, to classify the seedlings' quality, the morphological variables, such as plant height, stem base diameter, leaf area, and dry matter of the roots and aerial part are the most indicated (Binotto et al., 2010).

All these features are used to establish the morphological indexes, from which the most prominent ones are the relation between the plant height and the stem base diameter, the relation of the aerial part and root dry matter, and the Dickson quality index (Chaves \& Paiva, 2004). However, to evaluate the seedlings' quality, the features and the morphological indexes cannot be dealt with separately (Fonseca et al., 2002).

Therefore, we need to establish the container size to produce high-quality flamboyant seedlings and identify the variables that have a greater correlation with the seedlings' quality. Consequently, the purpose hereof was to evaluate the production of flamboyant seedlings [Delonix regia (Bojerex Hook.) Raf] in different-sized containers and perform a path analysis to identify the growth variables that characterize the quality of the produced seedling.

\section{Material and Methods}

\subsection{Location and Characterization of the Experimental Area}

The experiment was performed in a vegetation house at the Agronomic Experimental Station of the State University of Mato Grosso do Sul (UEMS), in Cassilândia, MS (19 $06^{\prime} 48^{\prime \prime}$ of South latitude; $51^{\circ} 44^{\prime} 03^{\prime \prime}$ of West longitude, and average altitude of $470 \mathrm{~m}$ ).

The regional climate, according to the Köppen classification is Aw, characterized as a tropical climate with hot summers and a tendency to high precipitation levels, and dry winters, with a dry season between May and September. The annual average temperature of 30 years is of $24.1^{\circ} \mathrm{C}$, with a minimum of $16.4{ }^{\circ} \mathrm{C}$ in July and a maximum of $28.6^{\circ} \mathrm{C}$ in January, and an annual average precipitation of $1.520 \mathrm{~mm}$. The temperature and relative humidity were daily monitored in the vegetation house through an Automatic Meteorological Station (CASSILANDIA-A742), and the data gathered during the experimental period (October 14 to January 30, 2017) are presented in Figure 1.

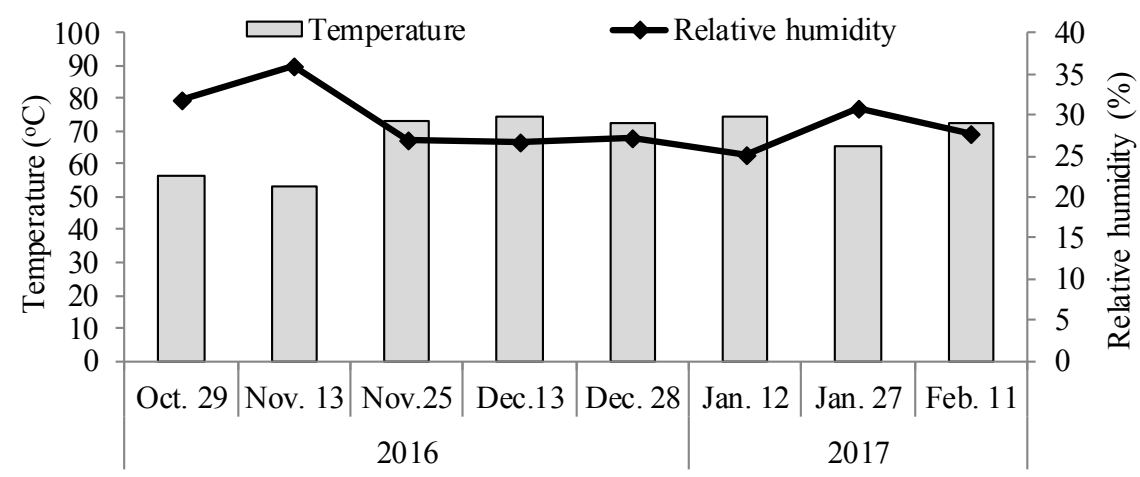

Figure 1. Mean temperature $\left({ }^{\circ} \mathrm{C}\right)$ and relative air humidity $(\%)$ within the greenhouse during the plant emergency period and formation of flamboyant [Delonix regia (Bojerex Hook.) Raf] seedlings 


\subsection{Substrate Used to Produce Seedlings}

The soil that was used was the Quartzarenic Neosol, collected in a pasture area at a layer of 0.0-0.20 m deep. After the collection, the soil was sieved and its chemical characteristics were analyzed according to EMBRAPA's instructions (2009). To know if it was necessary to treat the soil with lime, the base saturation method was used $(70 \%)$, which corresponds to the proportion of $2.20 \mathrm{Mg} \mathrm{ha}^{-1}$ (1.10 $\mathrm{g}$ of limestone per $\mathrm{dm}^{3}$ of soil). The limestone used had the following constitutions: $\mathrm{CaO}$ : $38 \%$; MgO: 11\%; PRNT: $85 \%$; PN: $62 \%$. After the liming, the manual homogenization of the soil was performed; then it was wet and kept under incubation for 30 days. After that period, the soil was mixed with bird manure at the proportion of 1:1 (v:v), forming the substrate that was used. The substrate's chemical features are presented in Table 1.

Table 1. Some chemical properties of the substrate used in the experiment

\begin{tabular}{|c|c|c|c|c|c|c|c|c|c|}
\hline $\mathrm{pH}$ & $\mathrm{P}_{\text {Mehlich-1 }}$ & O.M. & $\mathrm{H}+\mathrm{Al}$ & $\mathrm{Al}$ & $\mathrm{K}$ & $\mathrm{Ca}$ & $\mathrm{Mg}$ & CEC & $\mathrm{V}$ \\
\hline $\mathrm{CaCl}_{2}$ & $\mathrm{mg} \mathrm{dm}^{-3}$ & $\mathrm{~g} \mathrm{dm}^{-3}$ & \multicolumn{6}{|c|}{ 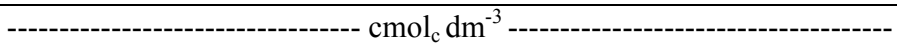 } & $\%$ \\
\hline 6.80 & 404 & 34.10 & 1.20 & 0.01 & 1.30 & 4.30 & 2.30 & 9.01 & 87 \\
\hline $\mathrm{S}_{-} \mathrm{SO}_{4}$ & \multicolumn{2}{|c|}{ B } & $\mathrm{Cu}$ & \multicolumn{2}{|r|}{$\mathrm{Zn}$} & & \multicolumn{3}{|c|}{$\mathrm{Mn}$} \\
\hline \multicolumn{10}{|c|}{ 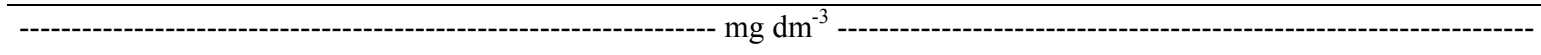 } \\
\hline 18.20 & \multicolumn{2}{|c|}{0.45} & 0.90 & \multicolumn{2}{|r|}{12.60} & & \multicolumn{3}{|c|}{76.80} \\
\hline
\end{tabular}

Note. O.M.: organic matter; V: base saturation; CEC: cation exchange capacity at $\mathrm{pH} 7$.

\subsection{Size of the Plastic Bags to Produce the Seedlings}

Seven container sizes were used with the following commercial dimensions: $13 \times 13,15 \times 15,13 \times 20,15 \times 25$, $17 \times 22,17 \times 30$, and $30 \times 40 \mathrm{~cm}$ (Table 2). The plastic bags were also characterized regarding their dimensions when filled with substrate, and the results are presented in Table 2.

Table 2. Commercial measurements of the plastic bags used in the experiment

\begin{tabular}{|c|c|c|c|c|c|}
\hline \multirow{2}{*}{ Commercial measurements } & Height & Width & Thickness & \multirow{2}{*}{$\begin{array}{l}\text { Volume* } \\
\text {---- } \mathrm{cm}^{3} \text {----- }\end{array}$} & \multirow{2}{*}{$\begin{array}{l}\text { Seedlings } \\
----\mathrm{m}^{2} \text {----- }\end{array}$} \\
\hline & \multicolumn{3}{|c|}{ 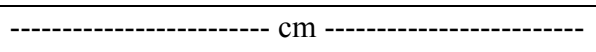 } & & \\
\hline $13 \times 13 \mathrm{~cm}$ & 10 & 7.5 & 6.0 & 450 & 222 \\
\hline $15 \times 15 \mathrm{~cm}$ & 12 & 8.5 & 6.0 & 612 & 196 \\
\hline $13 \times 20 \mathrm{~cm}$ & 17 & 8.0 & 5.5 & 748 & 227 \\
\hline $15 \times 25 \mathrm{~cm}$ & 21 & 8.5 & 6.0 & 1071 & 196 \\
\hline $17 \times 22 \mathrm{~cm}$ & 18 & 10 & 7.5 & 1350 & 133 \\
\hline $17 \times 30 \mathrm{~cm}$ & 26.5 & 10 & 7.0 & 1855 & 143 \\
\hline $30 \times 40 \mathrm{~cm}$ & 34 & 19 & 12 & 7752 & 44 \\
\hline
\end{tabular}

Note. ${ }^{*}$ Volume calculated from the multiplication of the following dimensions: height $\times$ width $\times$ thickness.

\subsection{Plant Material Employed}

The mature fruits of Delonix regia (Bojerex Hook.) Taf ("flamboyant") were harvested in twelve matrices, in a cerrado area located at the east region of the State of Mato Grosso do Sul, at the city of Cassilândia, MS $\left(23^{\circ} 47^{\prime} 40^{\prime \prime} \mathrm{S}\right.$ and $\left.54^{\circ} 41^{\prime} 07^{\prime \prime} \mathrm{W}\right)$, during the dry season, in August, 2016. The seeds were previously selected considering their size and weight and then subject to the dormancy break treatment with infusion in hot water $\left(95{ }^{\circ} \mathrm{C}\right)$, followed by infusion in water at room temperature $\left(24\right.$ to $\left.28{ }^{\circ} \mathrm{C}\right)$ during 24 hours. After the dormancy breaking, the seeds were immediately sown in the different-sized containers. Three seeds were sown by container, and twelve days after the seedlings' emergence, they were reduced to one plant by container. At 30 days after emergence (DAE), a nitrogen fertilization was performed (Urea - $45 \% \mathrm{~N}$ ) at the proportion of $50 \mathrm{mg}$ per $\mathrm{dm}^{3}$ of substrate, applied through irrigation water with about $20 \mathrm{~mL}$ of water by plant.

\subsection{Measuring the Plants' Growth and the Seedlings' Quality Indexes}

At the 20, 40,60, 80, and $100 \mathrm{DAE}$, the following features were evaluated: plant height-determined from the soil surface to the inclusion of the last leaf with the assistance of a millimeter ruler; diameter of the stem base-measured from the stem base level through readings made with a digital caliper (Clarke-150 mm), with a 
precision level of $\pm 0.01 \mathrm{~mm}$; height $(\mathrm{cm}) / \mathrm{stem}$ base diameter $(\mathrm{mm})$ relation $(\mathrm{PH} / \mathrm{SBD})$; number of leaves - through visual counting. At the $100^{\text {th }}$ day, the root volume was evaluated also: determined through the water displacement method, using a $100-\mathrm{mL}$ beaker graduated in millimeters $(\mathrm{mL})$ and therefore with a $\pm 1.0-\mathrm{cm}^{3}$ precision. Then, the plants were separated into aerial part and root system, deposited in paper bags and taken to a forced circulation greenhouse for 72 hours at $65{ }^{\circ} \mathrm{C}\left( \pm 1.0^{\circ} \mathrm{C}\right)$ to determine the root and aerial part dry matter, which were weighted in an analytic scale with a precision of $0.0001 \mathrm{~g}$. Based on these evaluations, we determined the total dry matter (TDM) and calculated the morphological indexes: relation between the aerial part/root dry matter (APDM/RDM); the sturdiness quotient (SQ) was determined based on the relation between the plant height, stem base diameter (PH/SBD), and the Dickson quality index (DQI). Based on the plant height $(\mathrm{PH})$, the stem base diameter (SBD), the aerial part dry matter (APDM), and the root dry matter (RDM) were calculated using the Equation 1, proposed by Dickson et al. (1960):

$$
\mathrm{DQI}=\frac{\mathrm{TDM}}{(\mathrm{PH} / \mathrm{SBD})+(\mathrm{APDM} / \mathrm{RDM})}
$$

Where, TDM is the total dry matter mass $(\mathrm{g})$; $\mathrm{PH}$ is the aerial part height $(\mathrm{cm})$; SBD is the stem base diameter $(\mathrm{mm})$; APDM is the aerial part dry matter $(\mathrm{g})$; and RDM is the root dry matter $(\mathrm{g})$.

\subsection{Experimental Plan and Statistical Analyses}

The experimental plan used was of assorted blocks, with containers of seven sizes $(13 \times 13 \mathrm{~cm} ; 15 \times 15 \mathrm{~cm} ; 13 \times$ $20 \mathrm{~cm} ; 15 \times 25 \mathrm{~cm} ; 17 \times 22 \mathrm{~cm} ; 17 \times 30 \mathrm{~cm}$, and $30 \times 40 \mathrm{~cm}$ ), with four repetitions. Each patch had five containers, totalizing 20 containers by treatment.

The experimental data were subjected to the normality and homogenization assumption verification tests. Such assumptions were not met in the case of the root volume, root dry matter, aerial part dry matter, and the Dickson quality index, whose data were transformed with the use of the square root of $(x+0.5)$ before the variance analysis. After the analysis of the transformed data, we checked if the assumptions were met. However, the data were presented at their original form. The data were subjected to the variance analysis (ANOVA), and when significant, the means were grouped by the Scott-Knott criterion at 5\% of probability, using the statistic program Sisvar $^{\circledR}$ version 5.3 for Windows (Statistic Analysis Software, UFLA, Lavras, MG, BRA).

To measure the direct and indirect effects of the growth features on the seedling's quality (DQI), the path analysis was performed, according to the methodology developed by Wright (1921). To that end, we performed the Pearson correlation analysis to obtain the correlation matrices and their significances by the "t" test, at a $5 \%$ probability level. The Pearson correlation coefficients were unfolded, obtaining the coefficients in the path analysis. The statistical analyses were performed using the statistical program Genes ${ }^{\circledR}$ version 5.1 for Windows (Statistic Analysis Software, UFV, Viçosa, MG, BRA). Before the path analysis, the multicollinearity diagnosis was performed, as detailed in Cruz and Regazzi (1997). The correlation matrix' multicollinearity level, among the independent variables of the regression model, was established based on its number of conditions, which is the ratio between the higher and lower eigenvalue of the phenotypic matrix. Therefore, when the condition number is less than 100, the multicollinearity is weak and do not generate any problem to the analysis; when its value is between 100 and 1,000, the multicollinearity is moderated to strong; and when it is greater than 1,000, the multicollinearity is severe (Montgomery \& Peck, 1981).

\section{Results and Discussion}

The results obtained indicate a significant effect of the different container sizes for every biometric feature of the evaluated flamboyant seedlings. Such fact is related to this species' growth rate linked to the great amplitude of the studied containers' dimensions. The substrate volume of the bigger container $\left(30 \times 40 \mathrm{~cm}-7752 \mathrm{~cm}^{3}\right)$ has about 17 times the amount of substrate of the smaller container $\left(13 \times 13 \mathrm{~cm}-450 \mathrm{~cm}^{3}\right)$ (Table 2).

At the evaluation of the flamboyant seedlings at $20 \mathrm{DAE}$, we noticed that the containers with the dimensions of $15 \times 25 \mathrm{~cm}, 17 \times 22 \mathrm{~cm}, 17 \times 30 \mathrm{~cm}$, and $30 \times 40 \mathrm{~cm}$ had the greatest values of plant height, sturdiness quotient, and number of leaves (Table 3). From $40 \mathrm{DAE}$, the seedlings grown in the $30 \times 40 \mathrm{~cm}$ container presented the greatest plant height in comparison with the other containers. At the 40 and $60 \mathrm{DAE}$, the containers with dimensions of $17 \times 30 \mathrm{~cm}$ and $30 \times 40 \mathrm{~cm}$ resulted in the greatest values of stem base diameter and number of leaves (Table 3). However, from 80 DAE, the bigger container resulted in the greatest values of stem base diameter and number of leaves in comparison with the other containers. For the sturdiness quotient, we noticed that there was no significant difference between the containers with the dimensions of $15 \times 25 \mathrm{~cm}, 17 \times 22 \mathrm{~cm}$, $17 \times 30 \mathrm{~cm}$, and $30 \times 40 \mathrm{~cm}$ for most evaluations, except at 40 DAE (Table 3 ). The greatest sturdiness coefficient values at $20 \mathrm{DAE}$ indicate that, initially, the flamboyant plants direct their photoassimilates to the seedling's height growth, and then to the stem base diameter. 
Table 3. Mean values of developmental characteristics measured for plant height, root collar diameter, plant height/collar diameter ratio and number of leaves at 20,40,60, 80 and 100 days after emergence (DAE) of the flamboyant [Delonix regia (Bojerex Hook,) Raf] seedlings grown in seven containers containing different substrate volumes. Cassilândia, MS, Brazil, 2017

\begin{tabular}{|c|c|c|c|c|c|}
\hline \multirow{2}{*}{ Measurements $(\mathrm{cm})$} & \multicolumn{5}{|c|}{ Evaluation time } \\
\hline & $20 \mathrm{DAE}$ & $40 \mathrm{DAE}$ & $60 \mathrm{DAE}$ & $80 \mathrm{DAE}$ & $100 \mathrm{DAE}$ \\
\hline & \multicolumn{5}{|c|}{----------------------------------------------- Plant height (cm) ---------------------------------------------- } \\
\hline $13 \times 13$ & $7.25 \pm 0.48 \mathrm{~b}$ & $9.58 \pm 0.64 \mathrm{c}$ & $10.33 \pm 0.36 \mathrm{~d}$ & $12.25 \pm 0.37 \mathrm{~d}$ & $12.37 \pm 0.13 \mathrm{~d}$ \\
\hline $15 \times 15$ & $7.37 \pm 0.42 \mathrm{~b}$ & $10.16 \pm 0.52 \mathrm{c}$ & $10.75 \pm 0.42 \mathrm{~d}$ & $12.33 \pm 0.69 \mathrm{~d}$ & $12.37 \pm 0.85 \mathrm{~d}$ \\
\hline $13 \times 20$ & $7.64 \pm 0.20 \mathrm{~b}$ & $11.83 \pm 0.52 \mathrm{~b}$ & $13.66 \pm 0.91 \mathrm{~d}$ & $15.41 \pm 0.98 \mathrm{~d}$ & $17.00 \pm 0.94 \mathrm{~d}$ \\
\hline $15 \times 25$ & $8.33 \pm 0.30 \mathrm{a}$ & $13.16 \pm 1.58 \mathrm{~b}$ & $22.00 \pm 2.23 \mathrm{c}$ & $25.33 \pm 2.48 \mathrm{c}$ & $28.75 \pm 2.98 \mathrm{c}$ \\
\hline $17 \times 22$ & $8.41 \pm 0.46 \mathrm{a}$ & $14.00 \pm 0.61 \mathrm{~b}$ & $20.91 \pm 1.42 \mathrm{c}$ & $24.41 \pm 2.01 \mathrm{c}$ & $26.50 \pm 2.76 \mathrm{c}$ \\
\hline $17 \times 30$ & $8.45 \pm 0.38 \mathrm{a}$ & $13.08 \pm 0.62 \mathrm{~b}$ & $27.41 \pm 1.12 \mathrm{~b}$ & $32.58 \pm 1.25 \mathrm{~b}$ & $34.37 \pm 2.54 \mathrm{~b}$ \\
\hline $30 \times 40$ & $8.50 \pm 0.46 \mathrm{a}$ & $18.16 \pm 0.64 \mathrm{a}$ & $32.16 \pm 2.20 \mathrm{a}$ & $46.75 \pm 3.10 \mathrm{a}$ & $49.18 \pm 2.43 \mathrm{a}$ \\
\hline \multirow[t]{2}{*}{$\mathrm{CV}(\%)$} & 9.38 & 13.07 & 15.44 & 15.91 & 16.99 \\
\hline & \multicolumn{5}{|c|}{----------------------------------------- Root collar diameter (mm) --------------------------------------.- } \\
\hline $13 \times 13$ & $2.64 \pm 0.06 \mathrm{~b}$ & $4.05 \pm 0.23 \mathrm{~b}$ & $6.13 \pm 0.22 \mathrm{~b}$ & $8.24 \pm 0.25 \mathrm{~d}$ & $10.50 \pm 0.22 \mathrm{~d}$ \\
\hline $15 \times 15$ & $2.45 \pm 0.14 \mathrm{~b}$ & $3.70 \pm 0.54 \mathrm{~b}$ & $5.53 \pm 0.52 \mathrm{~b}$ & $7.50 \pm 0.40 \mathrm{~d}$ & $9.80 \pm 0.65 \mathrm{~d}$ \\
\hline $13 \times 20$ & $2.41 \pm 0.20 \mathrm{~b}$ & $3.98 \pm 0.42 \mathrm{~b}$ & $6.08 \pm 0.24 \mathrm{~b}$ & $8.05 \pm 0.28 \mathrm{~d}$ & $10.16 \pm 0.23 \mathrm{~d}$ \\
\hline $15 \times 25$ & $2.60 \pm 0.12 \mathrm{~b}$ & $3.65 \pm 0.33 \mathrm{~b}$ & $6.68 \pm 0.17 \mathrm{~b}$ & $9.07 \pm 0.37 \mathrm{c}$ & $10.85 \pm 0.36 \mathrm{c}$ \\
\hline $17 \times 22$ & $2.43 \pm 0.11 \mathrm{~b}$ & $3.80 \pm 0.15 \mathrm{~b}$ & $6.68 \pm 0.13 \mathrm{~b}$ & $8.96 \pm 0.18 \mathrm{c}$ & $11.72 \pm 0.38 \mathrm{c}$ \\
\hline $17 \times 30$ & $2.75 \pm 0.14 \mathrm{a}$ & $4.80 \pm 0.09 \mathrm{a}$ & $8.87 \pm 0.43 \mathrm{a}$ & $11.44 \pm 0.26 \mathrm{~b}$ & $13.90 \pm 0.34 \mathrm{~b}$ \\
\hline $30 \times 40$ & $3.05 \pm 0.07 \mathrm{a}$ & $5.23 \pm 0.12 \mathrm{a}$ & $9.66 \pm 0.43 \mathrm{a}$ & $14.43 \pm 0.44 \mathrm{a}$ & $17.77 \pm 0.34 \mathrm{a}$ \\
\hline \multirow[t]{2}{*}{$\mathrm{CV}(\%)$} & 8.41 & 12.67 & 9.94 & 6.93 & 6.33 \\
\hline & \multicolumn{5}{|c|}{---------------------------------------------- Sturdiness quotient ---------------------------------------------' } \\
\hline $13 \times 13$ & $3.65 \pm 0.24 \mathrm{~b}$ & $2.38 \pm 0.22 \mathrm{c}$ & $0.84 \pm 0.05 \mathrm{~b}$ & $1.48 \pm 0.05 \mathrm{~b}$ & $1.18 \pm 0.02 \mathrm{~b}$ \\
\hline $15 \times 15$ & $3.68 \pm 0.21 \mathrm{~b}$ & $2.49 \pm 0.32 \mathrm{c}$ & $0.98 \pm 0.06 \mathrm{~b}$ & $1.64 \pm 0.06 \mathrm{~b}$ & $1.26 \pm 0.03 \mathrm{~b}$ \\
\hline $13 \times 20$ & $3.82 \pm 0.10 \mathrm{~b}$ & $2.88 \pm 0.21 \mathrm{~b}$ & $1.12 \pm 0.05 \mathrm{~b}$ & $1.91 \pm 0.11 \mathrm{~b}$ & $1.67 \pm 0.12 \mathrm{~b}$ \\
\hline $15 \times 25$ & $4.16 \pm 0.14 \mathrm{a}$ & $3.03 \pm 0.14 \mathrm{~b}$ & $1.63 \pm 0.14 \mathrm{a}$ & $2.75 \pm 0.24 \mathrm{a}$ & $2.44 \pm 0.22 \mathrm{a}$ \\
\hline $17 \times 22$ & $4.20 \pm 0.23 \mathrm{a}$ & $3.57 \pm 0.19 \mathrm{a}$ & $1.57 \pm 0.12 \mathrm{a}$ & $2.79 \pm 0.22 \mathrm{a}$ & $2.45 \pm 0.30 \mathrm{a}$ \\
\hline $17 \times 30$ & $4.23 \pm 0.19 \mathrm{a}$ & $3.68 \pm 0.11 \mathrm{a}$ & $1.55 \pm 0.09 \mathrm{a}$ & $2.85 \pm 0.11 \mathrm{a}$ & $2.48 \pm 0.22 \mathrm{a}$ \\
\hline $30 \times 40$ & $4.24 \pm 0.23 \mathrm{a}$ & $3.77 \pm 0.08 \mathrm{a}$ & $1.65 \pm 0.04 \mathrm{a}$ & $3.23 \pm 0.12 \mathrm{a}$ & $276 \pm 0.12 \mathrm{a}$ \\
\hline \multirow[t]{2}{*}{$\mathrm{CV}(\%)$} & 9.38 & 11.75 & 12.71 & 12.50 & 15.48 \\
\hline & \multicolumn{5}{|c|}{ 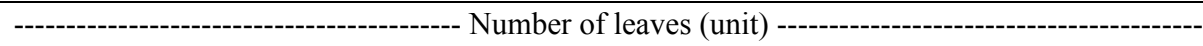 } \\
\hline $13 \times 13$ & $4.0 \pm 0.4 \mathrm{~b}$ & $7.0 \pm 0.3 \mathrm{~b}$ & $9.0 \pm 0.4 \mathrm{~b}$ & $10.0 \pm 0.1 \mathrm{~b}$ & $10.0 \pm 0.9 \mathrm{~b}$ \\
\hline $15 \times 15$ & $4.0 \pm 0.4 \mathrm{~b}$ & $7.0 \pm 0.3 \mathrm{~b}$ & $9.0 \pm 0.3 \mathrm{~b}$ & $10.0 \pm 0.8 \mathrm{~b}$ & $10.0 \pm 0.1 \mathrm{~b}$ \\
\hline $13 \times 20$ & $4.0 \pm 0.3 \mathrm{~b}$ & $7.0 \pm 0.3 \mathrm{~b}$ & $9.0 \pm 0.5 \mathrm{~b}$ & $11.0 \pm 0.7 \mathrm{~b}$ & $11.0 \pm 1.0 \mathrm{~b}$ \\
\hline $15 \times 25$ & $5.0 \pm 0.3 \mathrm{a}$ & $7.0 \pm 0.6 \mathrm{~b}$ & $10.0 \pm 0.7 \mathrm{~b}$ & $12.0 \pm 0.2 \mathrm{~b}$ & $12.0 \pm 0.6 \mathrm{~b}$ \\
\hline $17 \times 22$ & $5.0 \pm 0.2 \mathrm{a}$ & $7.0 \pm 0.4 \mathrm{~b}$ & $11.0 \pm 0.5 \mathrm{~b}$ & $12.0 \pm 0.5 \mathrm{~b}$ & $12.0 \pm 0.2 \mathrm{~b}$ \\
\hline $17 \times 30$ & $5.0 \pm 0.2 \mathrm{a}$ & $9.0 \pm 0.4 \mathrm{a}$ & $13.0 \pm 2.0 \mathrm{a}$ & $14.0 \pm 0.3 \mathrm{~b}$ & $14.0 \pm 0.7 \mathrm{~b}$ \\
\hline $30 \times 40$ & $5.0 \pm 0.1 \mathrm{a}$ & $9.0 \pm 0.2 \mathrm{a}$ & $14.0 \pm 1.0 \mathrm{a}$ & $18.0 \pm 1.9 \mathrm{a}$ & $19.0 \pm 2.0 \mathrm{a}$ \\
\hline $\mathrm{CV}(\%)$ & 9.15 & 10.12 & 18.24 & 12.99 & 17.07 \\
\hline
\end{tabular}

Note. Averages followed by the same letter belong to the same group by the Scott-Knott test at $95 \%$ confidence; $\mathrm{CV}$ : coefficient of variation, (means $\pm \mathrm{SE}$ ).

Similar results were obtained by other authors with different tree species. Purple ipe seedlings [Tabebuia impetiginosa (Mart. ex D.C.) Standl] produced in black polyethylene bags of $20 \times 36.5 \mathrm{~cm}$ and $15 \times 32 \mathrm{~cm} \mathrm{had}$ greater height and diameter (Cunha et al., 2005). With Pacara earpod tree, according to Abreu et al. (2015), the black polyethylene bags of $14 \times 20 \mathrm{~cm}$ resulted in greater values of plant heights, stem base diameters, and sturdiness quotients. In both papers, the authors noticed the direct relation between the increase of the container's size and the addition of these growth biometric features. Such result may be a result of the greater volume of the container, which provides more physical space and nutrients. 
At the height of plants up to $100 \mathrm{DAE}$, we noticed a daily increase of $0.12,0.12,0.17,0.29,0.27,0.34$, and 0.49 $\mathrm{cm} \mathrm{day}^{-1}$ on the containers with the dimensions of $13 \times 13 \mathrm{~cm}, 15 \times 15 \mathrm{~cm}, 13 \times 20 \mathrm{~cm}, 15 \times 25 \mathrm{~cm}, 17 \times 22 \mathrm{~cm}$, $17 \times 30 \mathrm{~cm}$, and $30 \times 40 \mathrm{~cm}$, respectively. In other words, during the development, the flamboyant plants grown in the container of greater volume had the maximum daily increase. This fact may be related to the containers limiting the plants' growth according to the seedlings' permanence in the nursery. That becomes evident in the containers of $13 \times 13 \mathrm{~cm}$ and $15 \times 15 \mathrm{~cm}$ because from 80 to 100 DAE there was practically no growth in height and/or increase in the number of leaves by plant. Therefore, for such containers, the flamboyant seedlings should remain on them for 80 DAE tops.

The sturdiness quotient, according to Carneiro (1995), is one of the main features to evaluate the quality of forest seedlings because it provides information regarding the plant height and the stem base diameter, informing if the seedling is weakened or hypertrophied. The seedlings presented sturdiness quotient values under 6.0, a value considered as the superior limit to result in greater survival of seedlings after their transplant under field conditions, especially in windy and dry places (Thompson, 1985). This author also states that a sturdiness quotient above 6.0 is undesirable because it is an indication that the seedlings are weakened and, therefore, have a lower survival capability in the field after their transplant.

Generally, we noticed that the $30 \times 40 \mathrm{~cm}$ container favored the growth of the roots and aerial part of the plants (Figure 2). Therefore, we can consider that the plants sown in such container had a greater root volume (Figure $2 \mathrm{a}$ ), root dry matter mass (Figure 2b), aerial part dry matter (Figure 2c), total dry matter (Figure 2d), aerial part dry matter/root dry matter relation (Figure 2e), and Dickson quality index (Figure 2f). However, for the aerial part dry matter/root dry matter relation, there was no significant difference with the dimensions of $15 \times 25 \mathrm{~cm}$, $17 \times 22 \mathrm{~cm}$, and $17 \times 30 \mathrm{~cm}$. These results are similar to the ones obtained by Abreu et al. (2015), who noticed greater values of root dry matter, aerial part dry matter, and Dickson quality index in Pacara earpod trees grown in the larger container. 

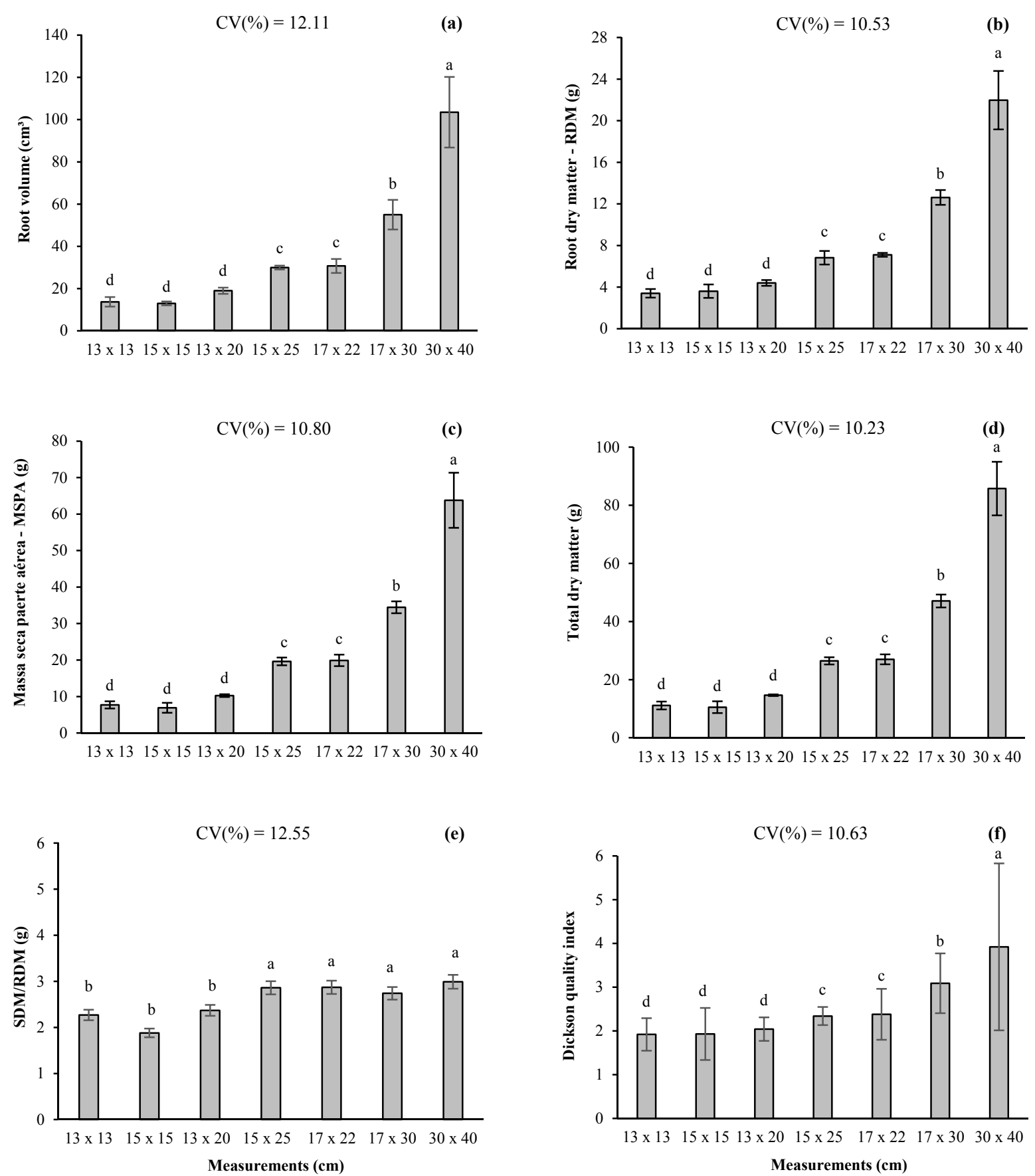

Figure 2. Root volume (a), root dry matter (b), shoot dry matter (c), total dry matter (d), shoot/root dry matter ratio - SDM/RDM (e) and Dickson quality index (f) of the flamboyant (Delonix regia (Bojerex Hook, Raf) seedlings grown in seven containers containing different volumes of substrate. Means followed by the same letter belong to the same group by the Scott-Knott test to $95 \%$ probability (means $\pm \mathrm{SE}$ ). Cassilândia, MS, Brazil, 2017.

The greatest container resulted in the increase of the number of leaves (Table 3). We know that the leaves have photosynthesizing organs for the biological production of photoassimilates. The plants with the greater number of leaves probably resulted in greater rates of photosynthesis and, consequently, in a greater quantity of photoassimilates available to be distributed to the drains (root system and aerial part). According to Campos et al. (2008), the greater amount of leaves on the seedlings will result in an intense photosynthetic activity and, consequently, the plants' growth in height and diameter will be greater. 
The flamboyant plant root system, when grown in the $7752 \mathrm{~cm}^{3}$ volume $(30 \times 40 \mathrm{~cm})$ container (Figures $2 \mathrm{a}$ and $2 b$ ), got the greater amount of nutrients due to the container's volume available for exploitation. According to Andrade et al. (2012), the greater containers provided a greater area for exploitation and a better spatial distribution of the root system, enabling a greater water and nutrient absorption. This variable reflects in a strong influence on the plant's growth and development (Taiz \& Zeiger, 2009). Therefore, the greater values for the flamboyant plants grown in the $30 \times 40 \mathrm{~cm}$ container in the variables root volume (Figure 2a), root dry matter (Figure 2b), aerial part dry matter (Figure 2c), and total dry matter (Figure 2d) are a result of the greater water and nutrient absorption, and consequently in a greater rate of photosynthesis and photoassimilate production.

For the APDM/RDM relation, we noticed that there was no difference between the containers of $15 \times 25 \mathrm{~cm}, 17$ $\times 22 \mathrm{~cm}, 17 \times 30 \mathrm{~cm}$, and $30 \times 40 \mathrm{~cm}$, whose values were $2.86,2.87,2.74$, and 2.99 , respectively (Figure 2e). This fact may be linked to the balanced growth between the different organs of the plant in these containers, considering that there was no change in the relative distribution of dry matter with the size variation of the container. These values are superior to the ones obtained by Oliveira et al. (2011), who, while evaluating three container sizes $(20 \times 30 \mathrm{~cm} ; 28 \times 40 \mathrm{~cm}$, and $40 \times 60 \mathrm{~cm})$ to produce Copernicia hospita seedlings (Copernicia hospita Martius, Palmae family), obtained values between 0.23 and 1.87 for this variable. According to Brissette et al. (1991), the best relation between these parameters should have a value of 2.0. Therefore, these container sizes resulted in seedlings with an APDM/RDM relation value above the recommended, indicating that, during the photoassimilate division between the aerial part and the roots, the aerial part got a greater share.

The Dickson quality index (DQI) represents the relation between the seedling's total dry matter and the sum of the quotient in sturdiness and dry matter of the aerial part and of the roots (Dickson et al., 1960), and since several parameters are necessary to obtain it, it is considered an excellent determinant of the seedlings' quality. Regarding the DQI's estimates, we notice that the values obtained are superior to the ones proposed by Hunt (1990) as minimum DQI values for good-quality seedlings (DQI $=0.2)$. However, his work was performed with coniferous species, and the DQI was developed based on pinus spp. species (Dickson et al., 1960). Hereon, the flamboyant seedlings presented DQIs of 1.92 to 3.92 (Figure 2b), indicating, therefore, the high quality of the seedlings produced in every container. Generally, greater DQI values indicate more vigorous seedlings and, consequently, a better quality. With that in mind, the $30 \times 40 \mathrm{~cm}$ container is the ideal one to grow flamboyant seedlings due to its greater mean.

To Fonseca et al. (2002), the data of the morphological parameters and the relations used to evaluate the seedlings' quality should not be treated separately in the standard classification of the seedlings' quality. Therefore, based on the plant height, on the stem base diameter, on the root volume, on the root dry matter, on the aerial part dry matter, on the total dry matter, on the sturdiness quotient, on the APDM/RDM, and on the DQI, we identified hereon that the container with the dimensions $30 \times 40 \mathrm{~cm}$ has the favorable characteristics to produce flamboyant seedlings.

We also underscore that the $30 \times 40 \mathrm{~cm}$ container has the greatest volume in comparison with all the other evaluated ones; it has about $7752 \mathrm{~cm}^{3}$ and it uses about 44 plastic bags per $\mathrm{m}^{2}$ in the nursery (Table 2). The containers with greater volumes promote better conditions for the seedlings' development, but they should be used only with species that have a slow development and need to remain in the nursery for a very long time, or when we wish to obtain well developed seedlings to plant them in urban areas, for example (Cunha et al., 2005). The authors also state that the input, workforce, and transportation requirements impose limits to the size of the containers made to produce seedlings, requiring the establishment of the better cost/benefit relation. Consequently, when these factors impose limits, we can use the $17 \times 30 \mathrm{~cm}$ container because it presents mean values under the seedlings sown on the $30 \times 40 \mathrm{~cm}$ container but is satisfactory to grow good-quality seedlings. Additionally, this substrate requires a volume of about $1855 \mathrm{~cm}^{3}$ and occupies around 143 plastic bags per $\mathrm{m}^{2}$ in the nursery. In other words, using this container represent an economy of about $76 \%$ of substrate and will fit around three times more containers in a similar area.

In multicollinearity, while using the correlation matrix's eigenvalue and eigenvector test on the primary independent variables of this model, we notice that the number of conditions is equal to $281647.69(\mathrm{CN}=$ 281647.69), that is, a severe multicollinearity. Therefore, we used the ridge regression (Hoerl \& Kennard, 1970) to calculate the model's coefficients and then avoid the multicollinearity effects. Accordingly, we adopted the value of $k=0.107$ to calculate the path coefficients (Table 4). Due to the presence of a severe multicollinearity, they prove themselves unstable as $\mathrm{K}$ increased until it was stabilized at the value of $\mathrm{k}=0.107$. 
Table 4. Estimates of the direct and indirect effects and the coefficient of determination $\left(\mathrm{R}^{2}\right)$ obtained by the Dickson quality index (DQI), plant height (PH), stem base diameter (SBD), number of leaves (NL), root volume (RV), root dry matter (RDM), shoot dry matter (SDM), total dry matter (TDM), sturdiness quotient (SQ) and shoot/root dry matter ratio (SDM/RDM) obtained in seedlings of flamboyant [Delonix regia (Bojerex Hook,) Raf] grown in seven containers containing different volumes of substrate. Cassilândia, MS, Brazil, 2017

\begin{tabular}{llllllllll}
\hline Effect of DQI & PH & SBD & NL & RV & RDM & SDM & TDM & SQ & SDM/RDM \\
\hline Direct & 0.093 & 0.167 & 0.088 & 0.167 & 0.181 & 0.160 & 0.163 & 0.004 & -0.053 \\
Indirect via PH & - & 0.087 & 0.083 & 0.089 & 0.089 & 0.090 & 0.089 & 0.084 & 0.078 \\
Indirect via SBD & 0.157 & - & 0.158 & 0.165 & 0.165 & 0.165 & 0.165 & 0.121 & 0.112 \\
Indirect via NL & 0.079 & 0.084 & - & 0.086 & 0.085 & 0.085 & 0.085 & 0.059 & 0.053 \\
Indirect via RV & 0.160 & 0.165 & 0.162 & - & 0.167 & 0.167 & 0.167 & 0.127 & 0.115 \\
Indirect via RDM & 0.173 & 0.179 & 0.174 & 0.180 & - & 0.180 & 0.180 & 0.138 & 0.124 \\
Indirect via SDM & 0.155 & 0.159 & 0.154 & 0.160 & 0.160 & - & 0.160 & 0.126 & 0.115 \\
Indirect via TDM & 0.158 & 0.162 & 0.157 & 0.163 & 0.163 & 0.163 & - & 0.128 & 0.116 \\
Indirect via SQ & 0.004 & 0.003 & 0.003 & 0.003 & 0.003 & 0.003 & 0.003 & - & 0.004 \\
Indirect via SDM/RDM & -0.045 & -0.036 & -0.032 & -0.037 & -0.036 & -0.038 & -0.038 & -0.050 & - \\
Total & $0.947 * *$ & $0.991 * *$ & $0.960^{* *}$ & $0.998^{* *}$ & $0.999 * *$ & $0.996 * *$ & $0.997 * *$ & $0.741 * *$ & $0.660^{* *}$ \\
Determination coefficient & 0.978 & & & & & & &
\end{tabular}

Note. ${ }^{* *}$ significant at the $1 \%$ level by the $\mathrm{t}$ test, respectively. Ns: not significant.

For the path analysis, we followed the model developed by Wright (1921) to better understand the links between several variables (Table 4). According to Nogueira et al. (2012), to interpret the correlations, we must consider three factors: the magnitude, the direction, and the significance. The eigenvalue of the coefficient of determination $\left(\mathrm{R}^{2}\right)$ in the path analysis model $(0.978)$ and the low effect of the residual variable $(0.158)$ showed that the adopted explanatory model expressed the primary variables' and of the DQI's cause and effect relation. Therefore, we notice through the $\mathrm{R}^{2}$ that these variables explained $97.8 \%$ of the DQI's variation.

The variables with positive correlation, with the main characteristic and with the direct effect in favorable direction, indicated the presence of the cause and effect relation (Silva et al., 2010). Therefore, we noticed that the stem base diameter, the root volume, the root dry matter, the aerial part dry matter, and the total dry matter culminated in a direct effect on the Dickson quality index. Such results are partially similar to the ones obtained by Dardengo et al. (2013), who noticed in robusta coffee (Coffea canephora) seedlings that only the total dry matter and stem base diameter variables had a great direct effect on the Dickson quality index.

Consequently, selecting flamboyant seedlings with greater root volume, root dry phytomass, aerial dry phytomass, and total dry phytomass will result in the indirect selection of seedlings with greater DQI. It is important to underscore that the stem base diameter is variable and not destructive; therefore, it is possible to select the good-quality seedlings without destroying them. Determining such variables is important to the quality of the flamboyant seedlings formed in different-sized containers.

\section{Conclusions}

The flamboyant seedlings grow better when grown in polyethylene bags with dimensions of $30 \times 40 \mathrm{~cm}$.

When the substrate, the nursery space, and the workforce are limiting factors to produce flamboyant seedlings, the container of $17 \times 30 \mathrm{~cm}$ can be used, although the quality of the produced seedlings will be inferior to the ones obtained on the $30 \times 40 \mathrm{~cm}$ container.

The stem base diameter, the root volume, the root dry matter, the aerial part dry matter, and the total dry matter are the most proper variables to indicate the flamboyant seedlings' quality, especially the stem base diameter due to its easy-measurement and non-destructive features.

\section{References}

Abreu, A. H. M., Leles, P. S. S., Melo, L. A., Ferreira, D. H. A. A., \& Monteiro, F. A. S. (2015). Produção de mudas e crescimento inicial em campo de Enterolobium contortisiliquum produzidas em diferentes recipientes. Floresta, 45(1), 141-150. https://doi.org/10.5380/rf.v45i1.28931 
Andrade, F. R., Petter, F. A., Marimon Júnior, B. H., Zuffo, A. M., Souza, T. R. S., \& Gonçalves, L. G. V. (2012). Formação de mudas de mamona em diferentes recipientes. Revista Brasileira de Ciências Agrárias, 7(2), 274-279. https://doi.org/10.5039/agraria.v7i2a1642

Ataíde, G. M., Bicalho, E. M., Dias, D. C. F. S., Castro, R. V. O., \& Alvarenga, E. M. (2013). Superação da dormência das sementes de Delonix regia (Bojer ex Hook.) Raf. Revista Árvore, 37(6), 1145-1152. https://doi.org/10.1590/s0100-67622013000600016

Binotto, A. F., Lúcio, A. D. C., \& Lopes, S. J. (2010). Correlations between growth variables and the Dickson quality index in forest seedlings. Cerne, 16(4), 457-464. https://doi.org/10.1590/s0104-77602010000 400005

Brissette, J. C., Barnett, T. J., \& Landis, T. D. (1991). Container seedlings. In M. L. Duryea \& P. M. Dougherty (Eds.), Forest regeneration manual (pp. 117-141). Dordrecht: Kluwer Academic Publishers. https://doi.org/ 10.1007/978-94-011-3800-0_7

Campos, M. C. C., Marques, F. J., Lima, A. G., \& Mendonça, R. M. N. (2008). Crescimento de porta-enxerto de gravioleira (Annona muricata L.) em substratos contendo doses crescentes de rejeitos de caulim. Revista de Biologia e Ciência da Terra Grande, 8(1), 61-66.

Carneiro, J. G. A. (1995). Produção e controle de qualidade de mudas florestais (p. 451). Curitiba: UFPR/FUPEF.

Chaves, A. de S., \& Paiva, H. N. de. (2004). Influência de diferentes períodos de sombreamento sobre a qualidade de mudas de fedegoso (Senna macranthera (Collad.) Irwin et Barn.). Scientia Forestalis, 65, 22-29.

Cruz, C. D., \& Regazzi, A. J. (1997). Modelos biométricos aplicados ao melhoramento genético (p. 390). UFV, Viçosa, Brasil.

Cruz, F. R. da S., Andrade, L. A. de, \& Feitosa, R. C. (2016). Produção de mudas de umbuzeiro (Spondias tuberosa Arruda Câmara) em diferentes substratos e tamanho de recipientes. Ciência Florestal, 26(1), 69-80. https://doi.org/10.5902/1980509821092

Cunha, A. O., Andrade, L. D., Bruno, R. D. L. A., Silva, J. D., \& Souza, V. D. (2005). Efeitos de substratos e das dimensões dos recipientes na qualidade das mudas de Tabebuia impetiginosa (Mart. Ex DC) Standl. Revista Árvore, 29(4), 507-516. https://doi.org/10.1590/s0100-67622005000400002

Dandengo, M. C. J., Sousa, E. F. De, Reis, E. F. dos, \& Gravina, G. A. (2014). Crescimento e qualidade de mudas de café conilon produzidas em diferentes recipientes e níveis de sombreamento. Coffee Science, 8(4), 500-509.

David, M. A., Mendonça, V., Reis, L. L., Silva, E. A., Tostas, M. S., \& Freire, P. A. (2008). Efeito de doses de superfosfato simples e de matéria orgânica sobre o crescimento de mudas de maracujazeiro amarelo. Pesquisa Agropecuária Tropical, 38(3), 147-152.

Dickson, A., Leaf, A. L., \& Hosner, J. F. (1960). Quality appraisal of white spruce and white pine seedling stock in nurseries. Forest Chronicle, 36(1), 10-13. https://doi.org/10.5558/tfc36010-1

Embrapa. Empresa Brasileira de Pesquisa Agropecuária. (2009). Manual de análises químicas de solos, plantas e fertilizantes (p. 627). Embrapa Solos, Embrapa Informática Tecnológica. Brasília, DF.

Fonseca, E. P., Valéri, S. V., Miglioranza, E., Fonseca, N. A. N., \& Couto, L. (2002). Padrão de qualidade de mudas de Trema micranta (L.) Blume, produzidas sob diferentes períodos de sombreamento. Revista Árvore, 26(4), 515-523. https://doi.org/10.1590/s0100-67622002000400015

Hoerl, A. E., \& Kennard, R. W. (1970). Ridge regression: Applications to nonorthogonal problems. Technometrics, 12(1), 69-82. https://doi.org/10.2307/1267352

Hunt, R. (1990). Plant growth curves (p. 75). Londres: Edward Arnold.

Lima, R. L. S., Severino, L. V., Silva, M. I. de L., Vale, L. S. do, \& Beltrão, N. E. de M. (2006). Volume de recipientes e composição de substratos para produção de mudas de mamoneira. Ciência e Agrotecnologia, 30(3), 480-486. https://doi.org/10.1590/s1413-70542006000300014

Lorenzi, H., Souza, H. M., Torres, M. A. V., \& Bacher, L. B. (2003). Árvores exóticas no Brasil: madeiras, ornamentais e aromáticas (p. 173). Nova Odessa: Instituto Plantarum. 
Lucena, A. M. A., Almeida, F. A. C., Costa, F. X., \& Guerra, H. O. C. (2006). Emprego de substratos irrigados com água de abastecimento e residuária na propagação do flamboyant. Revista de Biologia e Ciências da Terra, 6(1), 115-121.

Mafia, R. G., Alfenas, A. C., Siqueira, L., Leite, H. G., \& Cavallazzi, J. R. P. (2005). Critério técnico para determinação da idade ótima de mudas de eucalipto para plantio. Revista Árvore, 29(6), 947-953. https://doi.org/10.1590/s0100-67622005000600014

Montgomery, D. C., Peck, E. A., \& Vining, G. G. (1981). Introduction to linear regression analysis (p. 504). New York: John Wiley \& Sons.

Oliveira, A. B., Medeiros Filho, S., \& Bezerra, A. M. E. (2011). Tempo de cultivo e tamanho do recipiente na formação de mudas de Copernicia hospita. Acta Scientiarum Agronomy, 33(3), 533-538. https://doi.org/ 10.4025/actasciagron.v33i3.5443

Silva, J. I., Vieira, H. D., Viana, A. P., \& Barroso, D. G. (2010). Desenvolvimento de mudas de coffea canephora PIERRE ex A. FROEHNER em diferentes combinações de substrato e recipiente. Coffee Science, 5(1), $38-48$.

Taiz, L., \& Zeiger, E. (2009). Fisiologia vegetal (4th ed., p. 719). Porto Alegre: Artmed.

Thompson, B. E. (1985). Seedling morphological evaluation-What you can tell by looking. In M. L. Duryea (Ed.), Evaluating seedling quality: principles, procedures, and predictive abilities of major tests (pp. 59-71). Portland, Oregon, USA: Oregon State University.

Viana, J. S., Gonçalves, E. P., Andrade, L. A., Oliveira, L. S. B., \& Silva, E. O. (2008). Crescimento de mudas de Bauhinia forficata Link. em diferentes tamanhos de recipientes. Floresta, 38(4), 663-671. https://doi.org/10.5380/rf.v38i4.13161

Wendling, I., Paiva, H. N., \& Gonçalves, W. (2005). Técnicas de produção de mudas de plantas ornamentais (p. 223). Viçosa: Aprenda Fácil.

Wright, S. (1921). Correlation and causation. Journal of Agricultural Research, 20(7), 557-585.

\section{Copyrights}

Copyright for this article is retained by the author(s), with first publication rights granted to the journal.

This is an open-access article distributed under the terms and conditions of the Creative Commons Attribution license (http://creativecommons.org/licenses/by/4.0/). 